\title{
KEDUDUKAN HUKUM ANAK DILUAR KAWIN DALAM MENDAPATKAN SUATU WARISAN
}

\author{
Oleh : \\ Billy Verian Salim \\ Email : billyverians@gmail.com
}

\begin{abstract}
The inheritance law is a rule governing the legal consequences of a person's death against the intangible property: the transfer of wealth from the heir to the heirs. Either in the relationship of their fellow heirs or between them and the third party. The child is still open to the opportunity to inherit the property of his parents, with the record he has been recognized by his ayah-ibunya, while the right to justify the mother's possessions by the law is determined automatically without the need for a Recognition. Despite being born out of a legitimate marriage, the acknowledged child of marriage is a hereditary heir.
\end{abstract}

Keywords : law, child out of marriage, inheritance 


\section{PENDAHULUAN}

\subsection{Latar Belakang Masalah}

Perkawinan merupakan ikatan lahir bathin antara seorang pria dengan seorang wanita sebagai suami isteri dengan tujuan membentuk keluarga (rumah tangga) yang bahagia dan kekal berdasarkan Ketuhanan Yang Maha Esa. ${ }^{1}$ Pada dasarnya perkawinan bertujuan untuk membentuk keluarga yang bahagia dan kekal. Untuk itu suami isteri perlu saling membantu dan melengkapi, agar masing-masing dapat mengembangkan kepribadiannya membantu dan mencapai kesejahteraan sprituil dan material. $^{2}$

Suatu perkawinan tidak dapat dikatakan sempurna apabia tidak dikaruniai seorang anak oleh Tuhan Yang Maha Esa. Setiap anak yang lahir adalah buah dari perkawinan yang sah oleh kedua orang tua. Suatu ikatan perkawinan yang sah bisa dikatakan perkawinan tersebut didaftarkan ke Dinas Kependudukan dan Catatan Sipil (Dispendukcapil) ataupun Kantor Urusan Agama (KUA) sehingga mempunyai kedudukan sah di mata hukum. Apabila perkawinan tidak di daftarkan ke Dinas Kependudu-kan dan Catatan Sipil (Dispendukcapil) ataupun Kantor Urusan

1 Pasal 1 Undang-Undang No. 1 Tahun 1974 Tentang Perkawinan;

${ }^{2}$ Penjelasan Umum Undang-Undang No. 1 Tahun 1974 Tentang Perkawinan;
Agama (KUA) maka dapat dikatakan bahwa perkawinan tersebut tidak sah dimata hukum baik segi perkawinan tersebut ataupun anak-anak yang lahir dari perkawinan tersebut.

Mengingat kebayakan masyarakat pada umumnya melakukan hubungan suami istri belum pada waktunya. Sehingga terjadi permasalahan yang luar biasa, seringkali terjadi kelahiran seorang anak diluar adanya ikatan pernikahan yang sah. Anak yang lahir di luar suatu ikatan perkawinan yang sah disebut juga sebagai anak luar kawin. Dikalangan masyarakat sekitar, banyak yang menyebutkan juga anak diluar kawin disebut juga sebagai anak haram, tanpa adanya seorang bapak/ayah yang sah hasil pernikahan yang sah menurut hukum atau peraturan perundang-undangan yang berlaku di Negara Republik Indonesia. Sebagaimana dinyatakan dalam Pasal 43 ayat (1) UU Perkawinan menyatakan bahwa "Anak yang dilahirkan diluar perkawinan hanya mempunyai hubungan perdata dengan ibunya dan keluarga ibunya”.

Sebagaimana diketahui, anak yang lahir diluar kawin dalam mendapatkan hak-hak dalam hukum. Permasalahan mengenai hak yang harus di dapatkan oleh anak luar kawin merupakan hal yang penting dalam mendapatkan hak untuk hidup, hak untuk mendapatkan pen-didikan dan hak untuk mendapatkan pewarisan. 


\subsection{Perumusan Masalah}

Berdasarkan latar belakang yang telah dipaparkan di atas, maka permasalahan yang akan diteliti dapat dirumuskan sebagai berikut :

1. Apakah anak diluar perkawinan berhak mendapatkan suatu warisan?

2. Bagaimana penyelesaian jika terjadi sengketa dalam pembagian waris Islam?

\section{METODE PENELITIAN}

Tulisan ini menggunakan metode penelitian hukum normatif, yaitu meneliti hukum dari perspektif internal dengan objek penelitiannya adalah norma hukum. Dengan kata lain penelitian hukum yang meletakkan hukum sebagai sebuah bangunan sistem norma. Sistem norma yang dimaksud adalah mengenai asas-asas, norma, kaidah dari peraturan perundangan, putusan pengadilan, perjanjian serta doktrin (ajaran). ${ }^{3}$

Pendekatan yang digunakan adalah pendekatan perundang-undangan dan pendekatan konseptual. Pendekatan perundang-undangan atau statute approach digunakan jika permasalahan penelitiannya mempermasalahkan konflik norma yang terjadi secara vertikal maupun horizontal.

3 I Made Pasek Diantha, 2016, Metodologi Penelitian Hukum Normatif dalam Justifikasi Teori Hukum (Jakarta: Prenada Media Grup). Hlm.12
Dalam setiap penelitian atau survei terhadap sesuatu masalah dapatlah digunakan bermacam-macam cara atau metode seperti melakukan penelitian atau survei secara kepustakaan, melakukan interview dan sebagainya.

Pendekatan konseptual atau conceptual approach beranjak dari pandangan-pandangan dan doktrin-doktrin yang berkembang di dalam ilmu hukum, sehingga dapat menemukan ide-ide yang melahirkan pengertian-pengertian hukum, konsep-konsep hukum, dan asas-asas hukum yang relevan dengan isu yang dihadapi. ${ }^{4}$

\section{HASIL DAN PEMBAHASAN}

\subsection{Hak Anak Luar Kawin Untuk Mendapatkan Suatu Warisan}

Hukum waris adalah peraturan yang mengatur perpindahan kekayaan seseorang yang meninggal dunia kepada satu atau beberapa orang lain. ${ }^{5}$ Dari suatu pengertian tersebut dapat disimpulkan bahwa hukum waris adalah suatu peraturan yang mengatur akibat-akibat hukum dari kematian seseorang terhadap harta kekayaan yang berwujud: perpindahan kekayaan dari

\footnotetext{
Ibid, hlm. 159

5 Soebekti, 1983, Kaitan Undang-Undang Perkawinan dengan Penyusunan Hukum Waris, Kertas Kerja pada Simposium Hukum Waris Nasional, diselenggarakan oleh Badan Pembinaan Hukum Nasional, Jakarta, 10-12 Februari 1983.
} 
pewaris tersebut kepada para ahi waris. Baik dalam hubungan sesama ahli waris maupun antara mereka dengan pihak ketiga.

Oleh karena itu dalam suatu pewarisan terdapat 3 (tiga) unsur penting, yaitu : (1) adanya orang yang meninggal dunia selaku pewaris, (2). Adanya harta kekayaan yang ditinggalkan, (3). Adanya ahli waris. Yang dimaksud dengan Pewaris adalah orang yang meninggal dunia dengan meninggalkan suatu harta kekayaan. Sedangkan yang dimaksud dengan ahli waris adalah orang-orang yang menggantikan kedudukan si pewaris dalam bidang hukum harta kekayaan, karena meninggalnya pewaris. Sedangkan yang dimaksud dengan Warisan adalah harta kekayaan yang dapat berupa kumpulan aktiva dan pasiva dari si pewaris yang berpindah kepada para ahli waris. ${ }^{6}$

Testamen atau wasiat adalah pernyataan kehendak terakhir dari si pewaris mengenai apa yang dikehendaki akan terjadi dengan harta kekayaan sesudah ia meninggal dunia. Penunjukan seseorang sebagai ahli waris di dalam suatu testament atau wasiat disebut erfstelling.Pemberian warisan melalui testamen kepada orangorang tertentu atas barang-barang tertentu disebut legaat dan si penerima legaat

6 J. Andy Hartanto, 2015, Kedudukan dan Hak Waris Anak Luar Kawin menurut "Burgerlijk Wetboek" Pasca Putusan Mahkamah Konstitusi, LaksBang Justitia Surabaya, hlm.10 disebut legataris. Penunjukan ahli waris dan pemberian legaat termasuk dalam genus making. Dalam hukum pewarisan dapat dikenal sebagai legitieme portie, yaitu suatu bagian minimum dari warisan yang dijamin oleh Undang-Undang bagi ahli waris tertentu yang tidak boleh diganggu gugat oleh ahli waris lainnya. ${ }^{7}$

Hukum waris yang berpindah di dalam proses pewarisan adalah harta kekayaan di pewaris. Jadi, obyek hukum waris adalah harta kekayaan yang ditinggalkan oleh si pewaris (orang yang meninggal dunia) untuk dibagi bersama di antara para ahli waris sesuai dengan bagian masing-masing, baik menurut undangundang ataupun berdasarkan suatu wasiat. Harta kekayaan adalah semua hak-hak dan kewajiban yang dipunyai orang, yang mempunyai nilai uang. Demikian maka dapat dikatakan bahwa hukum waris merupakan hukum harta kekayaan

Anak luar kawin yang dapat diakui adalah anak yang dilahirkan oleh seseorang ibu, tetapi yang tidak dibenihkan oleh seorang pria yang berada dalaam ikatan perkawinan sah dengan ibu si anak tersebut, dan tidak termasuk dalam kelompok anak zinah dan anak sumbang. Menurut Hukum Islam, seseorang anak dikatakan sah apabila dilahirkan sekurangkurangnya enam bulan sesudah atau di

${ }^{7}$ Ibid, hlm. 11 
dalam tenggang masa tunggu (iddah), yaitu 4 bulan dan 10 hari sesudah perkawinan itu putus. ${ }^{8}$

Menurut Hukum Perdata Barat, syarat agar anak luar kawin dapat mewaris adalah bahwa anak luar kawin tersebut harus diakui secara sah oleh ayahnya. Karena menurut sistem KUH Perdata pada asasnya hanya mereka yang mempunyai hubungan hukum dengan si pewaris sajalah yang mempunyai hak waris menurut undang-undang. Hubungan hukum antara anak luar kawin dan orang tuamya lahir karena adanya suatu pengakuan. Sehingga anak-anak luar kawin berhak mewarisi harta orang tuanya.

Sebagaimana di dalam Kompilasi Hukum Islam mengenai Waris, Pasal 186, menjelaskan :"Anak yang lahir di luar perkawinan hanya mempunyai hubungan saling mewarisi dengan ibu dan keluarga pihak ibunya". Oleh karena itu dia hanya diwarisi oleh ibunya saja. Anak luar kawin masih terbuka peluang untuk mewarisi atas harta kekayaan orang tuanya, dengan catatan ia telah diakui oleh ayah-ibunya, sedangkan hak untuk mewaris terhadap harta ibu oleh Undang-Undang ditentukan secara otomatis tanpa memerlukan adanya suatu pengakuan.

\footnotetext{
Wirjono Prodjodikoro, 1981, Hukum Perkawinan di Indonesia, cetakan ke-7, Sumur Bandung, hlm.72
}

Anak luar kawin yang tidak diakui tidak akan menimbulkan suatu akibat hukum dalam pewarisan, karena anak luar kawin yang tidak diakui baik oleh ibunya maupun oleh bapaknya tidak dapat mewaris harta peninggalan orang tuanya. Sedangkan anak luar kawin yang diakui sah baik oleh ibunya maupun oleh bapaknya akan menimbulkan akibat hukum dalam pewarisan. Dengan adanya pengakuan tersebut akan mengakibatkan timbulnya hubungan perdata antara anak luar kawin yang diakui dengan orang tua yang mengakuinya. Anak luar kawin mendapat warisan dari ayahnya jika dia diakui secara sah oeh ayahnya dengan menggunakan Akta Pengakuan Anak secara autentik sesuai dengan Pasal 281 KUH Perdata.

Menurut Pasal 281 ayat (1) KUH Perdata : "Apabila anak luar kawin itu mewaris bersama-sama dengan anak sah atau janda atau duda yang hidup terlama dari pada si pewaris, maka anak luar kawin itu akan mewaris sepertiga bagian dari pada bagian anak sah".Jadi untuk menentukan bagian harus diterima oleh anak luar kawin yang diakui terlebih dahulu harus menentukan bagian yang ia terima seandainya ia adalah anak sah, kemudian baru bisa mengambil secara sepertiga.

Hak waris aktif anak luar kawin atas harta warisan pada hakekatnya sepenuhnya 
sama dengan hak dari keluarga sedarah yang sah, demikian juga saudara-saudara sedarah yang sah, demikian juga saudarasaudara sedarah luar kawin, ia merupakan ahli waris yang sesungguhnya. Hak waris pasif adalah apabila seorang anak luar kawin meninggalkan harta warisan yang harus dibagi-bagi di antara para hali warisnya baik anak-anak yang sah maupun anak-anak luar kawin. Pihak yang berhak atas harta warisan dari pewaris yang merupakan anak luar kawin, pertama-tama adalah keturunannya yang sah suami/ isteri yang hidup terlama.

Bagian warisan untuk anak luar kawin, berdasarkan Pasal 863 KUH Perdata adalah sebagai berikut :

a. Jika mewaris bersama Golongan I, maka mendapat $1 / 3$ bagian seandainya dia anak sah;

b. Jika mewaris bersama Golongan II dan Golongan III, maka mendapatkan 1/2 bagian dari seluruh harta peninggalan;

c. Jika mewaris bersama Golongan IV, maka mendapat $3 / 4$ bagian dari seluruh harta peninggalan;

d. Jika tidak ada satu pun ahli waris lain, maka seluruh harta peninggalan menjadi bagian anak luar kawin.

Meskipun lahir diluar perkawinan yang sah, anak luar kawin yang diakui adalah keturunan pewaris. Oleh karena itu anak luar kawin juga merupakan Legitimaris, sehingga memiliki hak mutlak selaku ahli waris (legitieme portie), yaitu $1 / 2$ bagian dari hak yang seharusnya dia terima jika dia anak sah. ${ }^{9}$

Perhitungan harta waris melalui Legitieme Portie. Legitieme Portie sama dengan bagian mutlak, yaitu bagian yang besarnya ditentukan oleh undang-undang. Dalam ketentuan Pasal 913 KUH Perdata disebutkan bahwa "Legitieme Portie adalah suatu bagian dari harta peninggalan yang harus diberikan kepada para waris dalam garis lurus menurut undang-undang, terhadap bagian mana si pewaris tak diperbolehkan menetapkan sesuatu baik selaku pemberian antara yang masih hidup maupun selaku wasiat".Legitieme Portie hanya ada untuk ahli waris $a b$ intestato dalam garis lurus, baik dalam garis lurus ke atas (adcendenten) maupun garis lurus ke bawah (decendenten), atau disebut juga ahli waris ab-intestato legitimaris. ${ }^{10}$ Ahli waris $a b$ intestatodalam garis lurus ke atas yaitu orang tua, kakek, nenek, sedangkan ahli waris ab intestato dalam garis lurus ke bawah yaitu, anak kandung dan anak angkat.

Ketentuan dalam Pasal 914 KUH Perdata menyebutkan bagian mutlak untuk anak kandung. Bagian mutlak anak

9 Irma Devita Purnamasari, 2014, Kiat-Kiat Cerdas, Mudah, dan Bijak Memahami Masalah Hukum Waris, Kaifa : Bandung, hlm. 111

10 Oemar Moechtar, 2019, Perkembangan Hukum Waris Praktik Penyelesaian Sengketa Kewarisan di Indonesia, Kencana. Surabaya, hlm. 87 
kandung bergantung dengan jumlah anak kandung yang ditinggakan. Apabila anak kandung yang ditingalkan, maka bagian mutlaknya adalah $1 / 2$ bagian dari harta yang ditinggalkan. Apabila dua orang anak kandung yang ditinggalkan maka bagian mutlaknya adalah $2 / 3$ bagian dari bagian yang sedianya diterima. Bukan dari harta peninggalan, sedangkan jika tiga orang atau lebih anak kandung yang ditinggalkan maka bagian mutlaknya adalah $3 / 4$ bagian dari bagian yang sedianya diterima, bukan dari harta peninggalan. ${ }^{11}$ Untuk memudahkan dalam menentukan Legitieme Portie untuk anak kandung, maka perhatikan contoh-contoh berikut ini:

Pertanyaan :

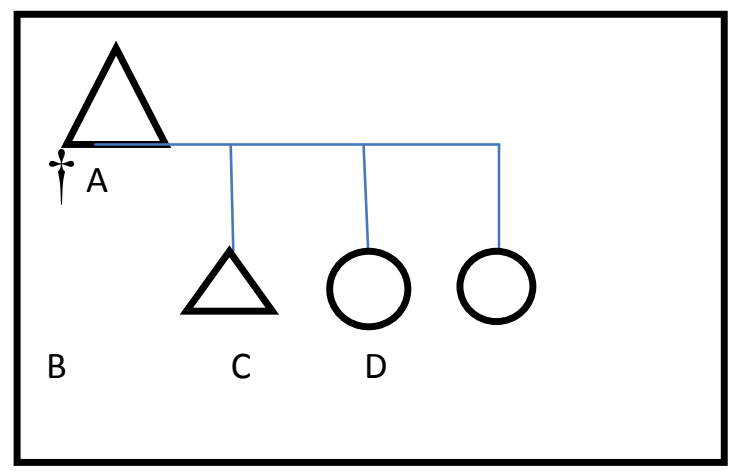

A Meninggal dunia meninggalkan tiga orang anak kandung bernama A, B, C, dan D. Berapa besarnya legitieme portie $\mathrm{BCD}$ ?

Dasar Hukum :Pasal 914 KUH Perdata. Dalam hal ini legitieme portie sebesar 3/4 karena pewaris meninggalkan tiga orang atau lebih anak kandung. Bagian $3 / 4$ ini di waris secara kolektif oleh bagian anak kandung.

Legitieme portie $\mathrm{BCD}$ adalah $3 / 4 \times 1 / 3$ $($ untuk BCD $)=1 / 4 \quad($ masing - masing dapat $1 / 4$ bagian ). Bagian bebas atau bagian sisa ( beschikbaar deel ) yang dapat diberikan kepada ahli waris testamenter yaitu sisa setelah diambil oleh ahli waris ab intestato legitimaris, yaitu $1-3 / 4-1 / 4$ bagian.

Legitieme portie dalam ketentuan Pasal 915 KUH Perdata. Didalam ketentuan Pasal 915 KUH Perdata disebutkan bahwa garis lurus ke atas bagian mutlak itu adalah selamanya setengah dari apa yang menurut undangundang menjadi bagian tiap-tiap mereka dalam garis itu dalam pewarisan karena kematian. Atau dengan kata lain dalam garis lurus ke atas, maka bagian yang diterima ahli waris dalam garis lurus ke atas yaitu, tetap $1 / 2$ bagian dari bagian menurut undang-undang menjadi bagian tiap-tiap mereka, waris ab intestato non legitimaris tidak perlu diperhatikan. Untuk memudahkan dalam pemahaman penerapan ketentuan Pasal 915 KUH Perdata, maka dapat dijelaskan sesuai dengan contoh berikut ini :

11 Ibid, hlm. 113. 
Pertanyaan :

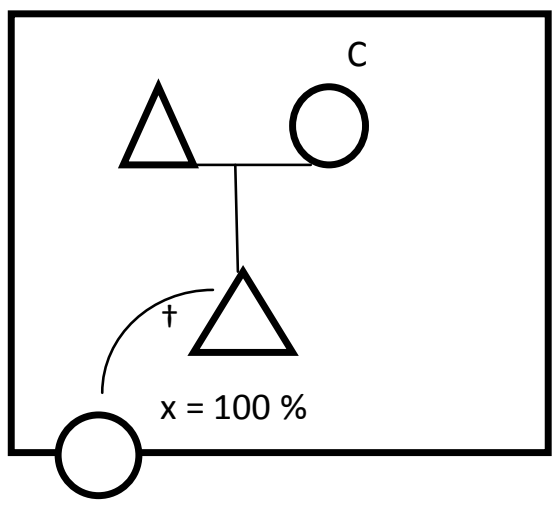

Kronologi Perkara :

A meninggal dunia, meningalkan orangtua kandungnya bernama $\mathrm{B}$ dan $\mathrm{C}$. Dalam wasiatnya, A mengangkat $X$ sebagai satu-satunya waris $(100 \%)$. Siapa ahli waris A dan berapa bagian warisnya ?

Dalam kasus diatas, A hanya meninggalkan ahli waris golongan kedua (ayah dan ibu) saja tanpa meninggalkan istri dan anak-anaknya. Dalam wasiatnya, A mengangkat X untuk menerima $100 \%$ hartanya, yang secara tidak langsung walaupun tidak dinyatakan tegas dalam wasiat, orang tua A yaitu B dan $\mathrm{C}$, di onterfd oleh A, sebab seluruh hartanya hanya diwaris oleh $\mathrm{X}$.

Namun perlu diperhatikan bahwa dalam kasus ini, B dan $\mathrm{C}$ merupakan ahli waris dalam lurus ke atas (adcedenten) yang mana berdasarkan ketentuan Pasal 915 KUH Perdata, B dan C memiliki legitieme portie yaitu sebesar $1 / 2$ dari bagian menurut undang-undang. Andai kata $\mathrm{B}$ dan $\mathrm{C}$ menurut legitieme portie maka berlakulah ketentuan Pasal 915 KUH Perdata jo Pasal 859 KUH Perdata. Dalam ketentuan Pasal 859 KUH Perdata disebutkan bahwa ayah atau ibu yang hidup terlama mewarisi seluruh harta peninggalan anaknya yang meninggal tanpa meninggakan keturunan, suami atau istri, saudara laki-laki atau perempuan. ${ }^{12}$ Karena dalam hal ini A tidak meninggalkan keturunan maka $\mathrm{B}$ dan $\mathrm{C}$ masing-masing seharusnya memperoleh $1 / 2$ bagian.

Namun karena ada wasiat yang isinya mengangkat X sebagai $100 \%$ harta warisan, maka berlakulah ketentuan Pasal 915 KUH Perdata. Legitieme portie dalam garis lurus ke atas adalah 1/2, maka jika dihubungkan dengan ketentuan Pasal 859 KUH Perdata maka perhitungannya sebagai berikut :

Legitieme Portie B = 1/2 (Pasal 915 KUH Perdata) x 1/2 (Pasal 859 KUH Perdata $)=1 / 4$ bagian

Legitieme Portie C = 1/2 (Pasal 915 KUH Perdata) x 1/2 (Pasal 859 KUH Perdata) $=1 / 4$ bagian.

$\mathrm{X}$ dalam hal ini memperoleh bagian sisa setelah dikurangi legitime portie, yaitu:

$$
\begin{aligned}
& =\text { Harta Waris }- \text { LP B }- \text { LP C } \\
& =1-1 / 4-1 / 4 \\
& =1 / 2
\end{aligned}
$$

Sehingga bagian waris yang harus diterima masing-masing yaitu :

12 Ibid, hlm. 115. 
$B=1 / 4$ bagian

$\mathrm{C}=1 / 4$ bagian

$X=1 / 2$ atau $2 / 4$ bagian.

Perkembangan hukum terkait dengan anak luar kawin, termasuk anak zina dan anak sumbang, diberikan oleh Mahkamah Konstitusi melalui Putusan Nomor : 46/ PUU-VIII/ 2010. Putusan tersebut menyatakan pada intinya menyatakan dua hal, yaitu : Pertama : Pasal 43 ayat (1) Undang-Undang Nomor 1 Tahun 1974 tentang Perkawinan yang menyatakan : "Anak yang dilahirkan di luar perkawinan hanya mempunyai hubungan perdata dengan ibunya dan keluarga ibunya", bertentangan dengan Undang-Undang Dasar Repubik Indonesia Tahun 1945 sepanjang dimaknai menghilangkan hubungan perdata dengan laki-laki yang dapat dibuktikan berdasarkan ilmu pengetahuan dan teknologi dan/ atau alat bukti lain menurut hukum ternyata mempunyai hubungan darah sebagai ayahnya.

Kedua, menyatakan Pasal 43 ayat (1) Undang-Undang Nomor 1 Tahun 1974 tentang Perkawinan tersebut tidak memiliki kekuatan hukum mengikat, sehingga ayat tersebut harus dibaca : “Anak yang dilahirkan di luar perkawinan hanya mempunyai hubungan perdata dengan ibunya dan keluarga ibunya serta dengan laki-laki sebagai ayahnya yang dapat dibuktikan berdasarkan ilmu pengetahuan dan teknologi dan/atau alat bukti lain yang menurut hukum mempunyai hubungan darah, termasuk hubungan perdata dengan keluarga ayahnya”. Namun pengakuan normatif dalam putusan Mahkamah Konstitusi (MK) tersebut diisyaratkan harus dapat dibuktikan berdasarkan ilmu pengetahuan dan teknologi dan/atau alat bukti lain menurut hukum

Kendati sebuah Putusan Mahkamah Konstitusi tersebut dianggap sebagai reformasi hukum terkait pengakuan hubungan perdata anak luar kawin dengan orang tua kandungnya, namun ternyata tidak diputuskan secara bulat. Salah seorang Hakim Konstitusi, yakni Maria Farida Indrati memiliki suatu alasan yang berbeda ( corcurring opinion) dalam putusan tersebut, bahwa tidak diakuinya hubungan keperdataan antara anak luar kawin dengan ayah kandungnya adalah sebagai suatu resiko dari perkawinan yang tidak tercatatkan menurut Undang-Undang Nomor 1 Tahun 1974 tentang Perkawinan.

Akibat putusan tersebut merupakan kerugian bagi laki-laki atau perempuan yang telah melakukan perkawinan, bukan suatu resiko anak yang harus di tanggung oleh anak yang telah dilahirkan. Oleh karena itu pemenuhan hak-hak anak yang terlahir dari suatu perkawinan, terlepas perkawinan tersebut sah atau tidak adalah 
tetap menjadi kewajiban orang tua kandung atau kedua orang tua biologisnya.

\subsection{Penyelesaian Jika Terjadi Sengketa}

\section{Dalam Pembagian Waris Islam}

Faraid (hukum waris Islam) adalah hukum yang mengatur tentang pemindahan hak pemindahan hak pemilikan harta peninggalan (tirkah) pewaris, menentukan siapa-siapa yang berhak menjadi ahli waris dan berapa bagian masing-masing. Dalam Islam istilah waris berasal dari kata warasah yang berarti hukum yang mengatur tentang pemindahan tirkah (hak pemilikan harta peninggalan) dari almuwaris (orang yang mewariskan) kepada al-waris (ahli waris) dengan menentukan siapa yang berhak menjadi ahi waris dan berapa hak atau bagian yang berhak untuk diterimanya. Dalam kitab fiqh waris tersebut dinamakan dengan istilah faraid, yang merupakan bentuk jamak dari faridah yang berasal dari kata fard, yang berarti ketentuan. $^{13}$

Hal yang membedakan hukum waris Islam dengan hubungan waris lainnya yaitu adanya penggolongan macam ahli waris yang berbeda-beda. Bagian warisan pun berbeda-beda bergantung kondisi kasus pewarisan. Dalam ketentuan Pasal 174 ayat (1) KHI disebutkan kelompokkelompok ahli waris terdiri dari : (a).

13 Rahmad Taufiq Hidayat. et al. 2000. Almanak Alam Islami Sumber Rujukan Keluarga Muslim Milenium Baru. Cetakan ke - 1, Jakarta : Dunia Pustaka Jaya, hlm. 332
Menurut hubungan darah, (i) golongan laki-laki terdiri dari : ayah anak laki-laki, saudara laki-laki, paman dan kakek, (ii) golongan perempuan terdiri dari : ibu, anak perempuan, saudara perempuan dari nenek, (b) menurut hubungan perkawinan terdiri atas : duda atau janda. namun apabila semua ahli waris ada, maka yang berhak mendapatkan warisan hanya : anak, ayah, janda atau duda. Ahli waris dalam Islam dibedakan menjadi tiga macam : (a). Dzawil furudz, (b) ashabah,dan (c) Mawaali atau ahli waris pengganti.

Pluralisme hukum waris di Indonesia berakibat berlakunya tiga macam hukum waris yang sama-sama berlaku, yakni : (1). Hukum waris Islam yang diperuntukan bagi warga negara yang beragama islam, (2). Hukum waris Barat atau Burgerlijk Wetboek yang diperuntukan bagi golongan Eropa dan golongan Timur Asing Tionghoa, (3). Hukum waris adat yang diperuntukan bagi golongan bumi putra yang tunduk pada hukum adat. Namun dalam praktiknya, warga negara yang beragama Islam, enggan menggunakan hukum waris Islam yang dinilai tidak memberikan keadilan.

Berdasarkan Yurisprudensi Mahkamah Agung Nomor : 172 K/ Sip/ 1974, Hukum yang diterapkan adalah hukum agama dari pewaris itu sendiri. Dengan adanya Yurisprudensi dari Mahkamah Agung tersebut, tidak dimungkinkan 
adanya pilihan hukum (choice of laws) dalam menentukan hukum waris yang akan diterapkan/ digunakan. Isi Yurisprudensi Mahkamah Agung Nomor : 172 K/ Sip/ 1974, yaitu :

a. Bagi warga negara yang beragama Islam, berlaku sistem hukum waris Islam;

b. Bagi warga negara yang bukan beragama islam, berlaku sistem hukum waris Barat (Burgerlijk Wetboek) atau hukum waris Barat.

Dalam hukum waris, pembagian harta warisan yang diberikan kepada ahli waris dalam prosesnya dapat berlangsung tanpa sengketa atau dengan sengketa. Pada prinsipnya pelaksanaan pembagian harta warisan berlangsung secara musyarawah. Musyawarah dilakukan oleh keluarga internal untuk menentukan bagian masingmasing ahli waris. Apabila musyawarah tidak dapat menyelesaikan sengketa, maka sengeketa tersebut diselesaikan melalui litigasi atau pengadian yang berwenang.

Cara menghitung kasus hukum waris Islam yang paling praktis yaitu dengan cara mengeluarkan terlebih dahulu bagian dzawil furudz (ahlli waris bagiannya telah ditentukan oleh AlQur'an), misalnya bagian ayah, ibu, janda, anak perempuan. Sisa di luar dzawil furudzyaitu : ashabah ,antara lain : (a). laki-laki, (b). Laki-laki mewaris bersama perempuan; dan (c). ayah. Bila tidak ada anak laki - laki, mendapatkan bagian sisanya. Apabila tidak ada ashabah bisa jadi dalam pewarisan terjadi perhitungan aul atau radd.

Menurut pendapat dari Moh. Anwar bahwa sebelum melakukan perhitungan asal masalah tersebut ada beberapa hal yang harus diperhatikan sebelumnya yang antara lain ${ }^{14}$ :

a. Menentukan siapa yang berhak menerima bagian dari ahli waris yang ada, dalam hal ini perlu untuk diihat siapa yang terhalang mewaris dan siapa yang tidak.

b. Menentukan beberapa besar bagian dari masing-masing ahli waris menurut ketentuan dari ahli waris dzawil furudzyang berhak menerima warisan tersebut dan menentukan siapa yang berhak menjadi ahli waris ashabah yang akan menerima kelebihan harta apabila ada.

c. Setelah menentukan hal-hal diatas, maka barulah dilakukan perhitungan menurut faraidh, namun dalam hal ini selain menentukan asal masalah perlu juga untuk memperlihatkan kemungkinan munculnya masalah aul dan / atau radd.

14 Moh.Anwar,. 1981. Faraid Hukum Waris dalam Islam dan Masalah-Masalahnya, Medan : al ikhlas, hlm. 39 


\section{PENUTUP}

\subsection{Kesimpulan}

Berdasarkan pembahasan diatas dapat ditarik kesimpulan sebagai berikut :

1. Oleh karena dalam suatu pewarisan terdapat 3 (tiga) unsur penting, yaitu : (1) adanya orang yang meninggal dunia selaku pewaris, (2). Adanya harta kekayaan yang ditinggalkan, (3). Adanya ahli waris. Yang dimaksud dengan Pewaris adalah orang yang meninggal dunia dengan meninggalkan suatu harta kekayaan. Sedangkan yang dimaksud dengan ahli waris adalah orang-orang yang menggantikan kedudukan si pewaris dalam bidang hukum harta kekayaan, karena meninggalnya pewaris. Sedangkan yang dimaksud dengan Warisan adalah harta kekayaan yang dapat berupa kumpulan aktiva dan pasiva dari si pewaris yang berpindah kepada para ahli waris.Testament atau wasiat adalah pernyataan kehendak terakhir dari si pewaris mengenai apa yang dikehendaki akan terjadi dengan harta kekayaan sesudah ia meninggal dunia. Penunjukan seseorang sebagai ahli waris di dalam suatu testament atau wasiat disebut erfstelling. Pemberian warisan melalui testamen kepada orang-orang tertentu atas barangbarang tertentu disebut legaat dan si penerima legaat disebut legataris.
Penunjukan ahli waris dan pemberian legaat termasuk dalam genus making.

2. Hal yang membedakan hukum waris Islam dengan hubungan waris lainnya yaitu adanya penggolongan macam ahli waris yang berbeda-beda. Bagian warisan pun berbeda-beda bergantung kondisi kasus pewarisan. Dalam ketentuan Pasal 174 ayat (1) KHI disebutkan kelompok-kelompok ahli waris terdiri dari : (a). Menurut hubungan darah, (i) golongan laki-laki terdiri dari : ayah anak laki-laki, saudara laki-laki, paman dan kakek, (ii) golongan perempuan terdiri dari : ibu, anak perempuan, saudara perempuan dari nenek, (b) menurut hubungan perkawinan terdiri atas : duda atau janda. namun apabila semua ahli waris ada, maka yang berhak mendapatkan warisan hanya : anak, ayah, janda atau duda. Ahli waris dalam Islam dibedakan menjadi tiga macam : (a). Dzawil furudz, (b) ashabah,dan (c) Mawaali atau ahli waris pengganti.

\subsection{Saran}

Hukum waris adalah peraturan yang mengatur perpindahan kekayaan seseorang yang meninggal dunia kepada satu atau beberapa orang lain. Jika pada nantinya terjadi pembagian waris maka dihitung dengan ahli waris sesuai dengan legitimie portie sesuai hak ahli waris, agar nantinya 
tidak timbul terjadinya sebuah sengketa. Jika tidak maka salah satu pihak tidak terima terkait pembagian waris tersebut.

DAFTAR PUSTAKA

Irma Devita Purnamasari, 2014, Kiat-Kiat Cerdas, Mudah, dan Bijak Memahami Masalah Hukum Waris, Kaifa : Bandung,

I Made Pasek Diantha, 2016, Metodologi Penelitian Hukum Normatif dalam Justifikasi Teori Hukum (Jakarta: Prenada Media Grup).

J. Andy Hartanto, 2015, Kedudukan dan Hak Waris Anak Luar Kawin menurut "Burgerlijk Wetboek" Pasca Putusan Mahkamah Konstitusi, LaksBang Justitia Surabaya

Oemar Moechtar, 2019, Perkembangan Hukum Waris Praktik Penyelesaian Sengketa Kewarisan di Indonesia, Kencana. Surabaya

Rahmad Taufiq Hidayat. et al. 2000. Almanak Alam Islami Sumber Rujukan Keluarga Muslim Milenium Baru. Cetakan ke - 1, Jakarta : Dunia Pustaka Jaya
Soebekti, 1983, Kaitan Undang-Undang Perkawinan dengan Penyusunan Hukum Waris, Kertas Kerja pada Simposium Hukum Waris Nasional, diselenggarakan oleh Badan Pembinaan Hukum Nasional, Jakarta, 10-12 Februari 1983.

Wirjono Prodjodikoro, 1981, Hukum Perkawinan di Indonesia, cetakan ke - 7, Sumur Bandung,

\section{Peraturan Perundang-undangan :}

- $\quad$ KUH Perdata

- Undang-Undang No. 1 Tahun 1974

- Tentang Perkawinan

- Kompilasi Hukum Islam (KHI)

- Yurisprudensi Mahkamah Agung Nomor : 172 K/ Sip/ 1974 


\section{BIODATA SINGKAT PENULIS}

BILLY VERIAN SALIM adalah Praktisi

Bidang Pekerja Migrant Indonesia.

Menyelesaikan pendidikan S1 pada

Fakultas Ekonomi Jurusan Manajemen,

President University, Bekasi. Pada saat ini sedang menyelesaikan program pendidikan S2 pada Fakultas Hukum Universitas Narotama Surabaya. 